FITRAH Jurnal Kajian Ilmu-ilmu Keislaman

Vol. 02 No. 2 Desember 2016

e-ISSN : 2460-2345, p-ISSN: 2442-6997

Web: jurnal.iain-padangsidimpuan.ac.id/index.php/F

\title{
EFEK MENONTON ACARA DI TELEVISI TERHADAP SOSIAL BUDAYA MASYARAKAT MUSLIM KOTA MEDAN
}

\author{
Oleh : Dr. Fahrul Rizal, M.Si \\ (Dosen Fak. Dakwah dan komunikasi UIN-SU Medan) \\ Email: fahrulrizalarsyady@yahoo.co.id
}

\begin{abstract}
Abstact
The research titled "Efek menonton acara iklan dan sinetron di televisi terhadap sosial budaya masyarakat muslim kota Medan". The purpose of this research was to determine whether watching advertisements and Cintron on television give effect to the Muslim communities in Medan include worship, family, and society. To get the data, the location determined in the district of Medan Belawan, Medan Deli and Medan Petisah with a population of 225598 with the sample 399 persons; then the data collected by using questionnaires. The data analyzed by using correlation Pearson and regression through SPSS. The result showed that watching advertisements and Cintron had very significant effect to social and culture of Muslim societies in Medan City.

Key words: advertisement, sinetron, social and culture.
\end{abstract}

\begin{abstract}
Abstrak
Penelitian ini berjudul "Efek menonton acara iklan dan sinetron di televisi terhadap sosial budaya masyarakat muslim kota Medan". Tujuan penelitian ini adalah untuk mengetahui apakah menonton iklan dan sinetron di televisi memberikan efek terhadap masyarakat muslim kota Medan yang mencakup beribadah, berkeluarga dan bermasyarakat. Untuk mendapatkan data, ditentukan lokasi penelitian di kecamatan Medan Belawan, Medan Deli, dan Medan Petisah dengan populasi sebanyak 225598. Ditetapkan sampel sebanyak 399 orang, pengumpulan data dengan angket. Penghitungannya menggunakan corelasi Pearson dan regresi berganda dengan alat bantu SPSS. Hasil dari penelitian ini menunjukkan bahwa menonton iklan dan sinetron memberikan efek yang sangat signifikan terhadap sosial budaya masyarakat muslim kota Medan.
\end{abstract}

Key word: Iklan, sinetron, sosial budaya

\section{PENDAHULUAN}

Media yang saat ini banyak dimanfaatkan dalam menyampaikan pesan adalah televisi. Meski lahir paling belakangan dibandingkan media massa cetak 
dan radio, namun pada akhirnya media televisi yang paling banyak diakses oleh oleh masyarakat di manapun di dunia ini ${ }^{1}$.

Goerge Gerbner, seorang pakar komunikasi dan peneliti televisi di Amerika menyebutkan bahwa televisi telah menjadi agama bagi masyarakat industri, televisi telah menggeser agama-agama konvensional. Khutbahnya didengar dan disaksikan oleh jamaah yang lebih besar dari pada jamaah agama manapun². Televisi sebagai media komunikasi massa merupakan satu kekuatan sosial yang dapat menggerakkan proses sosial ke arah suatu tujuan yang diinginkan. Akan tetapi untuk mengetahui secara tepat dan rinci mengenai kekuatan sosial yang dimiliki oleh komunikasi massa melalui televisi dan hasil yang dapat dicapainya dalam menggerakkan proses sosial tidaklah mudah. Oleh karena itu, efek televisi sebagai media komunikasi massa perlu dikaji secara lebih mendalam untuk mengetahui dengan jelas pengaruh dari media televisi tersebut.

Begitu besar pengaruh televisi terhadap kehidupan manusia baik secara individu maupun masyarakat luas, sehingga media massa televisi akhirnya melahirkan apa yang disebut dengan mass culture (kebudayaan massa). Daya tarik televisi yang cukup besar mampu merubah rutinitas manusia dan bahkan televisi menjadi panutan baru bagi kehidupan manusia. Hal ini tentu tidak mengherankan bila pada suatu saat nanti kebutuhan hidup manusia menjadi terpola dan terencana secara rutinitas, berdasarkan informasi media televisi yang hadir ke rumah pemirsanya dengan berbagai sajian informasi dan hiburan. Bukan tidak mungkin pula, manusia akan terbawa arus teknologi komunikasi massa yang pada akhirnya melepas dan menghilangkan ciri-ciri dan sifat human interest terhadap persoalan masyarakat secara umum. Dalam hal ini, kepentingan individualistik akan lebih menonjol dalam berbagai hal. Hanya orang-orang yang memiliki aspek ekonomi dan teknologi komunikasi massa yang dapat menguasai dunia secara tepat dan menguntungkan bagi perluasan kekuasaan individualistik. ${ }^{3}$

Siaran televisi tidak serta merta dapat mempengaruhi pemirsa. Dari berbagai kajian, siaran yang dapat berpengaruh terhadap pemirsa adalah siaran yang dilakukan berulang-ulang. Perulangan yang dimaksud bisa secara utuh diulang seperti iklan, bisa pula pengulangan pesan dengan format atau adegan yang berbeda. ${ }^{4}$

Siaran televisi yang menyampaikan pesan berulang-ulang diantaranya adalah iklan. Salah satu sifat iklan adalah reminder yaitu usaha untuk mengulang-ulang pesan iklan agar konsumen terus ingat tentang pesan serta produk barang dan jasa tertentu.

\footnotetext{
${ }^{1}$ Badjuri, Adi. Jurnalistik Televisi (Jogjakarta: Graha Ilmu, 2010), h. 11.

${ }^{2}$ Rakhmat, Jalaluddin. Islam Aktual (Bandung: Mizan, 1995), hlm. 75.

${ }^{3}$ Kuswandi, Wawan, Komunikasi Massa Sebuah Analisis Media Televisi (Jakarta : Rineka Cipta, 1996), h. 29.

${ }^{4}$ Rakhmat, Jalaluddin, Psikologi Komunikasi (Bandung: Rosda Karya, 2002), hlm. 242.
} 
Selain iklan, siaran televisi yang selalu menyampaikan pesan secara berulang-ulang adalah sinetron. Pesan yang disampaikan berulang-ulang misalnya pesan karekater pemeran utama, gaya hidup, pakaian dan lainnya.

Indikasi besarnya terpaan siaran televisi bagi masyarakat kota Medan dapat terlihat dengan cepatnya produk baru yang beredar di pasar. Gencarnya iklan sepeda motor Yamaha di televisi, membuat Yamaha saat ini menjadi kompetitor yang sangat serius dari Honda yang selama ini menjadi market leader (penguasa pasar) di kota Medan. Demikian juga iklan rokok Gudang Garam yang berani menjadi sponsor utama siaran langsung Liga Inggris di Golbal TV dan MNC TV (dahulu TPI), sampai saat ini masih mampu menguasai pasar rokok di Medan.

Sinetron berjudul "Tukang bubur naik Haji" yang ditayangkan RCTI hampir setiap malam, saat ini sedang banyak disaksikan oleh pemirsa di Kota Medan. Dari pengamatan yang selama ini dilakukan, sinetron ini banyak digemari pemirsa karena dinilai apa yang dikisahkan memiliki banyak kesamaan dengan apa yang terjadi di tengah masyarakat. Dengan banyaknya pemirsa yang menyaksikan, sedikit atau banyak akan memberikan pengaruh terhadap sosial budaya masyarakat kota Medan.

Begitu banyaknya indikasi besarnya kontribusi siaran televisi terhadap perubahan sosial budaya. Keadaan seperti ini yang membuat kajian tentang pengaruh siaran televisi terhadap masyarakat kota Medan menarik dan perlu dilakukan.

Adapun tujuan penelitian ini adalah untuk mengetahui tentang efek yang ditimbulkan oleh menonton iklan dan sinetron di televisi terhadao kehidupan sosial budaya masyaralat Muslim di kota Medan. Sementara, setelah penelitian ini selesai, diharapkan berguna :

1. Pengembangan ilmu komunikasi massa khususnya kajian tentang efek siaran televisi

2. Menambah wawasan tentang kehidupan sosial budaya masyarakat, khususnya di kota Medan

3. Bagi peneliti lain yang berminat meneliti tentang efek media massa atau kehidupan sosial budaya masyarakat

4. Sebagai bahan pertimbangan bagi pengelola siaran televisi dalam menayangkan siaran-siarannya.

5. Bagi masyarakat luas untuk lebih pintar memilih siaran-siaran yang baik bagi mereka.

\section{KERANGKA KONSEP DAN TEORI}

\section{Efek Pesan Media Massa Televisi}

Selain kehadirannya yang memberi efek terhadap khlayak, tidak kalah pentingnya adalah bahwa pesan-pesan yang disampaikan melalui media massa televisi juga memberikan efek yang tergolong kuat terhadap pemirsanya. Secera sederhana setidaknya ada tiga efek yang ditimbulkan dari media massa televisi, 
FITRAH Jurnal Kajian Ilmu-ilmu Keislaman

Vol. 02 No. 2 Desember 2016

yaitu efek pengetahuan dan pemahaman (efek kognitif), efek pembentukan dan perubahan sikap (efek afektif), dan efek pembentukkan dan perubahan perilaku (efek behavioral).

1. Efek kognitif yaitu kemampuan seseorang atau pemirsa untuk menyerap dan memahami acara yang ditayangkan televisi yang melahirkan atau menambah pengetahuan pemirsa, misalnya acara kuis ${ }^{5}$, atau acara lain yang menyajikan berbagai ilmu pengetahuan bagi pemirsanya. Efek kognitif merupakan akibat yang timbul pada diri komunikan yang sifatnya informatif bagi dirinya, baik itu tentang benda, orang, tempat ataupun peristiwa yang belum pernah mereka ketahui. Jalaluddin Rakhmat dengan mengutip pendapat Mc. Luhan menyebutkan bahwa media massa (termasuk televisi) merupakan perpanjangan panca indera. Dunia ini terlalu luas untuk dijangkau dan dimasuki oleh indera manusia, akan tetapi media televisi dapat membantu indera manusia untuk memperoleh informasi tentang lingkungan sosial, politik, kebudayaan, ekonomi dan religius, sebab televisi dapat menyampaikan berbagi informasi yang jauh dari jangkauan indera manusia. ${ }^{6}$ Dengan terbantunya indera manusia oleh media televisi, maka secara bersamaan akan bertambah pula pengetahuan manusia dalam banyak hal yang mereka saksikan melalui tayangan berbagai bentuk acara televisi.

2. Efek Afektif, yaitu efek pembentukan dan perubahan sikap. Efek ini kadarnya lebih tinggi daripada efek kognitif. Berdasarkan berbagai paket acara, terutama pendidikan, perubahan sikap pemirsa akan tampak, apakah perubahan sikap itu untuk sementara atau untuk jangka waktu yang cukup lama. ${ }^{7}$ Pembentukan dan perubahan sikap sebagai akibat pesan media televisi yang paling menonjol adalah identifikasi atau peniruan, yaitu pemirsa dihadapkan pada trendi aktual yang ditayangkan televisi, misalnya model pakaian, model rambut, dari bintang atau orang terkenal lainnya yang ditayangkan di televisi yang kemudian digandrungi atau ditiru secara fisik oleh para pemirsanya. ${ }^{8}$

3. Efek behavioral, yaitu merupakan akibat yang timbul pada diri khalayak (pemirsa) dalam bentuk perilaku, tindakan atau kegiatan. Dampak perilaku ini merupakan proses tertanamnya nilai-nilai sosial budaya yang ditayangkan televisi diserap oleh pemirsa dan diterapkan dalam kehidupan sehari-hari ${ }^{9}$. Pesan-pesan yang disampaikan media massa televisi secara terus-menerus akan memberi pengaruh perilaku khlayak (pemirsa). Adegan kekerasan dalam televisi atau film yang ditayangkan televisi akan menyebabkan orang menjadi bringas, begitu juga sinetron-sinetron remaja

${ }^{5}$ Wawan Kuswandi, Komunikasi Massa Sebuah Analisis Media Televisi, (Jakarta: Rineka Cipta,1996) hlm. 100.

${ }^{6}$ Rakhmat, Psikologi.., h. 224.

${ }^{7}$ Wawan Kuswandi, Komunikasi Massa..., hlm.102.

${ }^{8}$ Ibid. hlm. 100.

${ }^{9} \mathrm{Ibid}$ 
yang bertemakan sekolah yang selalu ditayangkan di televisi dengan menampilkan beberapa gaya kehidupan remaja di sekoah menyebabkan para remaja terpengaruh dan ikut bergaya seperti yang diskasikannya dalam sinetron tersebut. Begitu juga halnya, jika televisi banyak menyajikan acaraacara atau cerita mengandung unsur kekerasan, maka hal itu juga akan menyebabkan semakin banyak orang melakukan tindakan kekerasan. ${ }^{10}$

Bagaimanapun juga, bahwa media komunikasi massa televisi mempunyai efek tidak bisa dibantah, baik itu efek kognitif (pengetahuan), afektif (emosional dan perasaan), dan behavioral (perubahan pada perilaku). Dalam perkembangan komunikasi kontemporer saat ini, proses pengaruh (munculnya efek kognitif, afektif dan behavioral) tidak bisa bediri sendiri, dengan kata lain ada beberapa faktor yang ikut mempengaruhi proses penerimaan pesan. Jadi pesan itu tidak lansgung mengenai individu, tetapi disaring, dipikirkan dan dipertimbangkan apakah ia mau menerima pesan-pesan media massa televisi atau tidak. ${ }^{11}$ Faktor-faktor inilah yang ikut menjadi penentu besar tidaknya efek yang dilakukan media massa. Ada dua faktor utama yang bisa diskusikan yakni faktor individu dan faktor sosial.

1. Faktor Individu, faktor individu yang ikut berpengaruh pada proses penerimaan pesan lebih banyak dipengaruhi oleh pemikiran psikologi. Ada banyak faktor pribadi yang ikut mempengaruhi proses komunikasi antara lain selective attention, selective perception, dan selective retention, motivasi dan pengetahuan, kepercayaan, pendapat, nilai dan kebutuhan, pembujukan, kepribadian dan penyesuaian diri. Selective attention adalah individu yang cenderung menerima terpaan pesan media massa televisi yang sesuai dengan pendapat dan minatnya. Di samping itu, ia menghindari pesan-pesan yang tidak sesuai dengan pendapat dan minatnya. Bahkan dalm perkembangannya, seorang individu akan punya kecenderungan memilih siaran yang sesuai dengan sikap dan keyakinannya. Orang yang beragama Islam akan punya kecenderungan memperhatikan siaran agama Islam di televisi dibanding dengan siaran agama lainnya. Singkatnya jika ada beberapa informasi yang menerpa seseorang, ia akan cenderung memilih yang sesuai dengan pendapat dan minatnya. Selective perception adalah seorang individu secara sadar akan mencari media yang bisa mendorong kecenderungan dirinya, kecenderungan dirinya ini bisa pendapat, sikap atau keyakinan. Selective retention, adalah kecenderungan sesorang hanya untuk mengingat pesan yang sesuai dengan pendapat dan kebutuhan dirinya sendiri. Motivasi seseorang juga akan ikut menentukan sebua pesan diterima atau tidak. Motivasi seseorang untuk mencari hiburan misalnya akan menjadi dalih untuk menikmati acara televisi yang sifatnya menghibur, misalnya sinetron, acara komedi atau pagelaran musik. Seseorang yang

\footnotetext{
${ }^{10}$ Rakhmat, Psikologi.., hlm. 242.

${ }^{11}$ Ibid. h. 214.
} 
percaya bahwa hanya dengan memanfaatkan media massa masayarakat akan menjadi cerdas akan mendudukkan media massa sebagai satu-satunya faktor yang ikut mempengaruhi sikap dan perilakunya. Selain itu, seseorang menerima atau terpengaruh pesan-pesan media massa televisi jugatergantung pada pengaruh bujukan yang dilakukan orang lain. Kepribadian individu juga akan ikut membentuk proses penerimaan pesanpesan media televisi. Pribadi yang penyabar akan menyukai sajian acaraacara yang membutuhkan kesabaran. Di lain hal, terpaan media massa akan lebih mudah diterima oleh orang-orang yang biasa menyesuaikan diri dengan hal-hal baru. ${ }^{12}$

2. Faktor Sosial, Black dan Whitney seperti dikutip oleh Nurudin menyebutkan bahwa umur dan jenis kelamin masuk sebagai faktor sosial, dan merupakan faktor pertama yang mempengaruhi efek pesan. Menurut mereka bisa jadi umur atau jenis kelamin seseorang akan ikut mempengaruhi kepada kelompok mana ia bergabung. Jadi jenis kelamin dan umur ini berkaitan dengan lingkup sosial lembaga di mana individu bergabung. Organisasi dimana individu bergabung akan ikut menentukan bagaimana pesan media massa televisi mempengaruhi perilaku individu. Misalnya seseorang yang masuk organisasi tertentu, misalnya Pujakesuma, akan lebih mudah menerima pesan-pesan media massa televisi yang mendukung keberadaan Pujakesuma dan menolak kritik-kritik yang ditujukan pada Pujakesuma. Bahkan reaksi individu yang masuk sebuah organisasi seringkali rekatif sekali, artinya bisa jadi pesan-pesan media itu benar, tetapi karena ia berada dalam sebuah organisasi, maka pesan-pesan itu tidaklah begitu mengena pada diri individu itu. Pendidikan yang berbeda juga menentukan proses penerimaan pesan, mereka yang berpendidikan rendah biasanya lebih menyukai berita seks, kriminal dan kejahatan lain atau berita-berita bombatis, sementara mereka yang berpendidikan lebih tinggi bisanya tidaklah demikian. Pekerjaan dan pendapatan juga merupakan faktor yang mempengaruhi proses penerimaan pesan media komunikasi massa (termasuk televisi). Seorang pegawai bank atau mereka yang bekerja di sektor ekonomi akan lebih senang mengikuti berita, acara atau sajian yang berkaitan dengan masalah ekonomi. Begitu juga dengan pendapatan, mereka yang berpendapatan menengah atas mempunyai uang banyak akan berlangganan lebih dari satu koran, lebih dari satu televisi kabel, dan bahkan dalam menerima siaran televisi, mereka kerap kali menggunakan vasilitas tambahan yang memungkinan mereka untuk bisa menangkap siaran televisi dari berbagai penjuru dunia. Agama yang dianut juga turut mempengaruhi penerima pesan media televisi, agama dan organisasi keagamaan sesorang ikut menentukan proses penerimaan pesan, ikut menentukan acara mana yang akan dilihat di televisi. Agama menjadi faktor penentu atau menjadi

${ }^{12}$ Ibid. hlm. 220. 
pendorong motivasi seseorang untuk memanfaatkan pesan-pesan media massa. Tempat tinggal juga mempunyai pengaruh terhadap proses penerimaan dan efek pesan-pesan komunikasi massa. Makanya orang yang tinggal di Medan, misalnya akan lebih tertarik dengan berita-berita atau acara yang berkaitan dengan Medan. ${ }^{13}$

Secara empirik, efek atau pengaruh media massa televisi selain memberi efek bagi kemajuan dan pembangunan masyarakat, juga memiliki andil dalam pembentukan sikap, perilaku dan keadaan masyarakat, seperti berikut ini:

1. Penyebaran budaya global yang menyebabkan masyarakat berubah dari tradisional ke modern, dari modern ke post modern dan agamais menjadi sekuler.

2. Media massa kapitalis telah memicu hilangnya berbagai bentuk kesenian dan budaya tradisional di masyarakat yang semestinya dipelihara.

3. Terjadinya perilaku imitasi yang kadang menjurus kepada meniru hal-hal yang buruk dari apa yang dilihat dan saksikan melalui media televisi.

4. Efek media massa sering secara brutal menyerang seseorang dan merusak nama baik orang tersebut serta menjurus ke pembunuhan karakter seseorang.

5. Persaingan media massa yang tidak sehat menyebabkan media massa mengorbankan idealismenya dengan menyajikan berbagai pemberitaan yang justru menyerang norma-norma sosial, sehingga menyebabkan terciptanya perilaku pelanggaran norma sosial bahkan terciptanya perilaku menyimpang.

6. Penyebaran pemberitaan pornomedia menyebabkan lunuturnya lembaga perkawinan dan norma seks keluarga di masyarakat bahkan memicu terbentuknya penyimpangan perilaku seks di masyarakat.

7. Berita kekerasan dan teror di media massa televisi telah memicu terbentuknya ketakutan massa di masyarakat, masyarakat selalu merasa tidak aman, tidak menyenangkan, dan tidak tentram menjadi anggota masyarakat tertentu, karena dibayangi ketakutan berita-berita kekerasan dan kriminal yang ditayangkan oleh televisi.

8. Media massa televisi kapitalis telah berhasil mengubah masyarakat dari kota sampai ke desa menjadi masyarakat konsumeris dan masyarakat yang banyak bermimpi dan pemalas. Hal ini terjadi sebagai akibat dari penayangan berbagai acara televisi yang menonjolkan gaya hidup mewah ditambah lagi dengan berbagai iklan produk yang menggiurkan pemirsa.

9. Media massa televisi cenderung menjadi alat provokasi sebuah kekuasaan sehingga efek media massa menindas rakyat, bahkan dalam skala luas, media massa menjadi alat kolonialisme modern, dengan memihak kepada

${ }^{13}$ Ibid. hlm. 220-223. 
FITRAH Jurnal Kajian Ilmu-ilmu Keislaman

Vol. 02 No. 2 Desember 2016

suatu negara adidaya dan menjadi genderang perang untuk menyerang negara-negara kecil, miskin dan terbelakang. ${ }^{14}$

\section{Teori yang digunakan: . Social Norms Theory}

Titik tekan pada teori ini adalah kegagalan komunikasi dapat menimbulkan gangguan dan rintangan dalam pelaksanaan norma sosial. Kajian teori ini menjadi lebih luas karena dua hal: pertama luasnya ruang lingkup kajian norma sosial. Kedua, banyak faktor yang menyebabkan kegagalan dalam komunikasi.

Norma adalah aturan-aturan yang mapan tentang perilaku yang diteriam dan layak. ${ }^{15}$ Norma sosial berarti aturan-aturan yang mapan tentang perilaku yang diterima dan layak di tengah masyarakat tertentu. Norma sosial di satu masyarakat dapat berbeda di masyarakat lain, tergantung dari apa yang diterima dan dianggap layak oleh masing-masing masyarakatnya.

Hadirnya norma-norma sosial agar hubungan yang terjadi di dalam masyarakat sesuai dengan harapan. Lahirnya norma sosial memiliki tahapan. Awalnya terbentuk secara tidak sengaja. Namun lama kelamaan norma itu dibuat secara sadar, tertulis dan diberi sanksi bagi yang melanggarnya. Misalnya dahulu perantara jual beli (calo) tanah tidak diberi bagian dari proses jual beli. Tetapi lama kelamaan calo tanah telah ditentukan berapa persen baginnya, ditentukan pula siapa yang harus menanggung biaya calo. Bahkan calo tanah kini telah menjadi mata pencaharian yang dikelola secara profesional.

Cepat atau lambatnya penyebaran norma di tengah sosial, sangat tergnatung dari kuantitas dan kualitas komunikasi yang terjadi di tengah masyarakat. Anggota masyarakat yang tidak mengikuti norma baru karena kegagalan komunikasi, juga akan mendapatkan sanksi. Misalnya seseorang yang tidak memberikan bagian kepada calo tanahnya karena tidak memahami telah terjadinya pergeseran norma, akan dianggap orang yang tidak tahu berterimakasih.

\section{Kerangka Konsep}

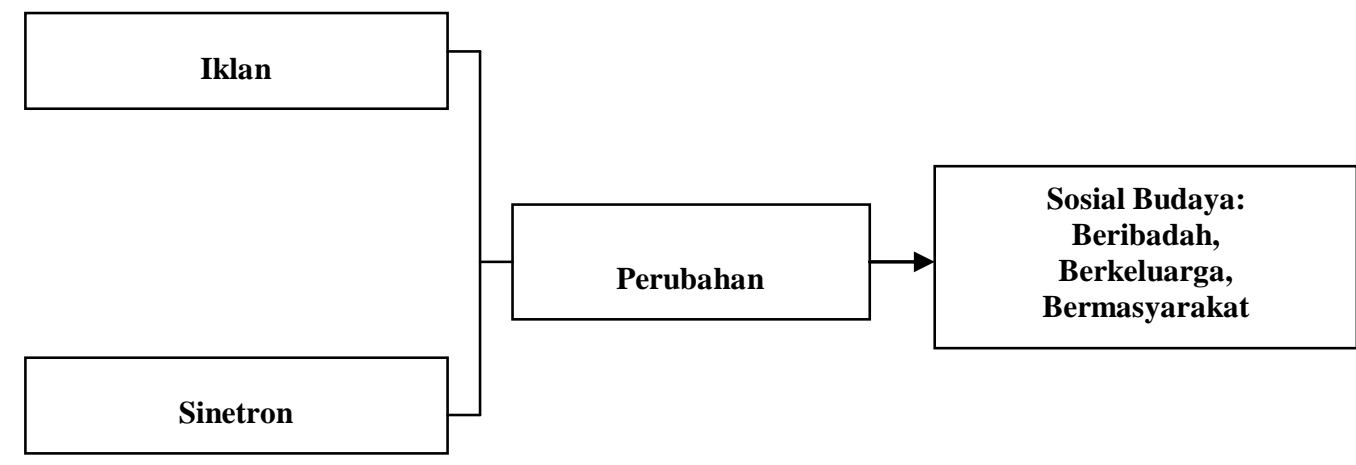

${ }_{14}$ Nashrillah, Pola Menonton Siaran Agama di Televisi dan Pengaruhnya Terhadap Pengamalan Agama Ibu-Ibu Pengajian Aisyiah Kecamatan Medan Timur-Tesis, (Medan: PPs IAIN-SU,2007), hlm. 42.

${ }^{15}$ Syaifullah, Ujang, Kapita Selekta Komunikasi, Bandung: Simbiosa Rekatama Media, 2007. hlm. 213. 
Dari kajian teori di atas, maka hipotesis yang diajukan dalam penelitian ini adalah sebagai berikut berikut:

1. Menonton iklan di televisi berpengaruh terhadap sosial budaya masyarakat muslim kota Medan.

2. Menonton sinetron di televisi berpengaruh terhadap sosial budaya masyarakat muslim kota Medan.

3. Menonton iklan, sinetron dan infotainmen di televisi secara bersama-sama berpengaruh terhadap sosial budaya masyarakat muslim kota Medan.

\section{METODE PENELITIAN}

Populasi dalam penelitian ini adalah seluruh masyarakat di 3 kecamatan dengan berbagai latar belakang agama yang berbeda yang berusia di atas 15 tahun. Jumlah populasi sebanyak 225598 orang ${ }^{16}$. Sampel adalah sebagian dari populasi yang dipandang mewakili populasi untuk dijadikan sebagai sumber data atau sumber informasi dalam suatu penelitian. ${ }^{17}$ Untuk menentukan jumlah sampel digunakan rumus Yamane. Dari hasil perhitungan, ditemukan jumlah sampelnya adalah $=399,288$ dibulatkan menjadi 399 orang. Untuk mendapatkan sampel yang benar-benar representatif, maka penarikan sampel dilakukan dengan menggunakan tahapan sebagai berikut:

a. penetapan sampel lokasi penelitian dengan tahapan penentuan 3 kecamatan, 3 kelurahan dengan masing-masing kriteria yang telah ditetapkan. Kemudian ke masing-masing lingkungan sampai kepada Rumah tangga.

b. Penetapan responden menggunakan metode stratified random sampling (sampel acak bertingkat).

$$
\text { Kerangka sampling Penelitian }
$$

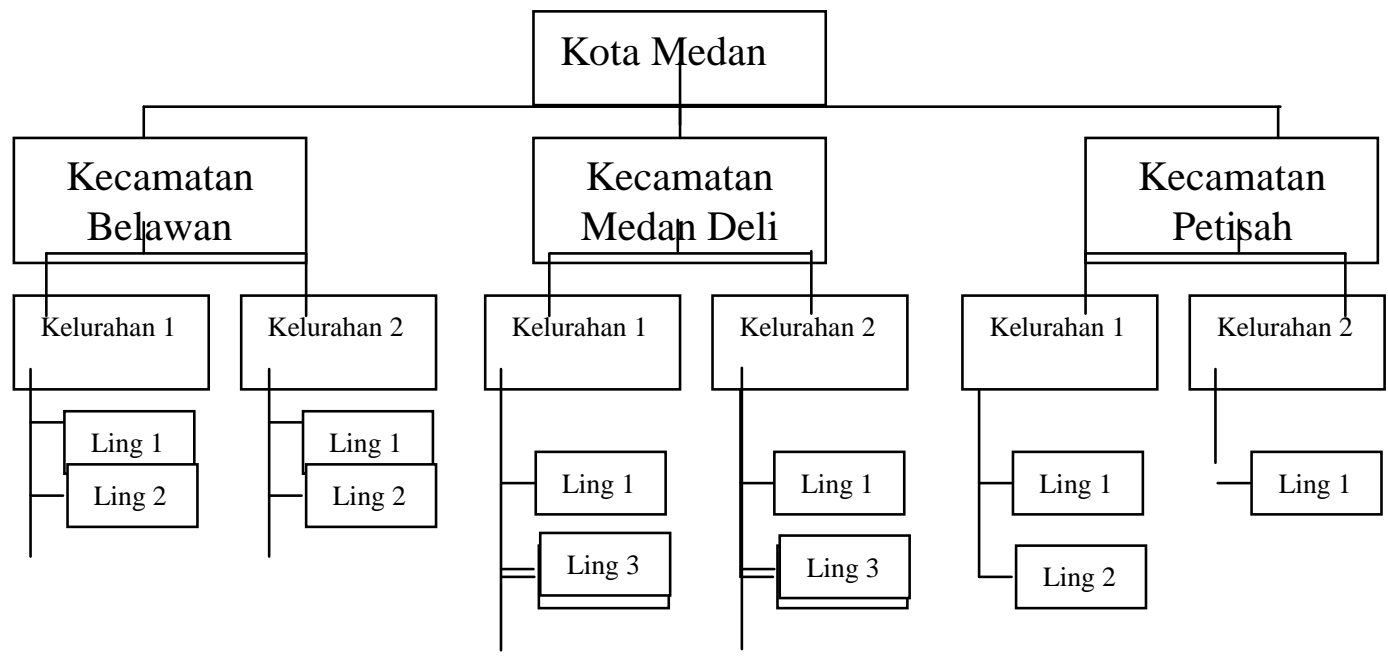

${ }^{16}$ BPS Kota Medan tahun 2011

17 Kholil ,Syukur, Metodologi Penelitian Komunikasi (Bandung: Citapustaka Media, 2006), hlm. 37 . 
FITRAH Jurnal Kajian Ilmu-ilmu Keislaman

Vol. 02 No. 2 Desember 2016

Rata-rata responden untuk masing-masing lingkungan 29 sampai 32 orang, sebanyak 13 lingkungan sehingga jumlah sampelnya menjadi 399 orang dengan sebaran masing-masing kecamatan sebagai berikut:

Tabel 1

Distribusi Sampel Penelitian

\begin{tabular}{clrrr}
\hline Nomor & Nama Kecamatan & $\begin{array}{c}\text { Jumlah } \\
\text { Penduduk }\end{array}$ & $\%$ & Jumlah Sampel \\
\hline 1 & Medan Belawan & 67102 orang & $30 \%$ & 119 orang \\
\hline 2 & Medan Deli & 108134 orang & $48 \%$ & 191 orang \\
\hline 3 & Medan Petisah & 50362 orang & $22 \%$ & 89 orang \\
\hline & & 225598 orang & $100 \%$ & 399 orang \\
\hline
\end{tabular}

Penelitian ini secara umum terdiri dari dua variabel, yaitu variabel bebas (menonton siaran di televisi mencakup siaran iklan, sinetron) dan variabel terikat (sosial budaya mencakup ibadah sosial, berkeluarga dan bermasyarakat). Untuk mengukur ketiga variabel tersebut digunakan kuisioner, dengan kisi-kisi instrumen sebagai berikut:

Tabel 2

Variabel Penelitian dan Indikator Pengukuran

\begin{tabular}{|c|c|c|}
\hline Variabel & Sub Variabel & Indikator \\
\hline \multirow{9}{*}{$\begin{array}{l}\mathrm{X} 1= \\
\text { Iklan }\end{array}$} & \multirow[t]{3}{*}{ Makanan } & Motiv menonton \\
\hline & & Keseriusan menonton \\
\hline & & Frekuensi menonton \\
\hline & \multirow{3}{*}{$\begin{array}{l}\text { Hiburan/gaya } \\
\text { hidup }\end{array}$} & Motiv menonton \\
\hline & & Keseriusan menonton \\
\hline & & Frekuensi menonton \\
\hline & \multirow{3}{*}{$\begin{array}{l}\text { Pakaian, } \\
\text { kendaraan, rumah }\end{array}$} & Motiv menonton \\
\hline & & Keseriusan menonton \\
\hline & & Frekuensi menonton \\
\hline \multirow{9}{*}{$\begin{array}{l}\mathrm{X} 2= \\
\text { Sinetron }\end{array}$} & \multirow[t]{3}{*}{ Remaja } & Motiv menonton \\
\hline & & Keseriusan menonton \\
\hline & & Frekuensi menonton \\
\hline & \multirow[t]{3}{*}{ Keluarga } & Motiv menonton \\
\hline & & Keseriusan menonton \\
\hline & & Frekuensi menonton \\
\hline & \multirow[t]{3}{*}{ Agama } & Motiv menonton \\
\hline & & Keseriusan menonton \\
\hline & & Frekuensi menonton \\
\hline \multirow{5}{*}{$\begin{array}{l}\mathrm{Y}= \\
\text { Sosial Budaya }\end{array}$} & \multirow[t]{2}{*}{ Ibadah sosial } & Zakat, Infaq dan sedekah \\
\hline & & Silaturrahmi keagamaan \\
\hline & \multirow[t]{3}{*}{ Berkeluarga } & Keluarga inti \\
\hline & & Keluarga seayah ibu \\
\hline & & Keluarga besar \\
\hline
\end{tabular}


Efek Menonton Acara di Televisi Terhadap..... FAHRUL RIZAL

\begin{tabular}{lcl}
\hline Variabel & Sub Variabel & Indikator \\
\hline & Bermasyarakat & Di tempat tinggal \\
\cline { 2 - 2 } & & Di pekerjaan \\
\cline { 2 - 2 } & & Pergaulan umum \\
\hline
\end{tabular}

Berdasarkan permasalahan pada penelitian dan metode yang digunakan, maka instrumen yang digunakan dengan model skala likert. Selanjutnya, teknik pengumpulan data yang digunakan penulis adalah kuesinoner. Sebelum disebarkan kepada responden, sebelumnya kuesioner dilakukan uji coba. Uji coba kuesioner ini dilakukan kepada 30 responden penelitian di luar sampel. Tujuannya adalah untuk memastikan bahwa alat ukur yang akan digunakan itu benar-benar andal untuk mengukur apa yang akan diukur. Ada dua jenis instrumen, yaitu keshahihan instrumen (validitas) dan kehandalan instrumen (realibilitas). Dari seluruh item kuessioner yang diuji coba menunjukkan angka valid dan hasil uji coba reliabilitas angket, ditemukan angkat 0,82. Dengan demikian berarti reliabilitas datanya tergolong tinggi. Pengujian hipotesis satu dan dua dengan menggunakan teknik korelasi Pearson, dan dikonsultasikan dengan regresi sederhana. Sedangkan hipotesis ke tiga akan diuji dengan menggunakan teknik regresi berganda. Kedua teknik penghitungan ini akan dihitung dengan alat bantu SPSS. Data-data yang bersifat kualitatif yang diperoleh dari hasil wawancara dengan para tokoh dan ahli akan dipaparkan secara deskriptif.

\section{HASIL PENELITIAN}

Pada penelitian ini, ada 3 hipotesis yang adiuji, yaitu :

\section{Pengujian Hipotesis 1}

Hipotesis 1 adalah "Menonton iklan di televisi berpengaruh terhadap sosial budaya masyarakat muslim kota Medan". Sosial budaya masyarakat muslim mencakup : ibadah sosial, berkeluarga dan bermasyarakat. Hipotesis ini diuji dengan menggunakan korelasi Peason.

Berdasarkan perhitungan dengan menggunakan alat bantu SPSS, diketahui bahwa $(b)$ tidak sama dengan nol $(b \neq 0)$. Dengan demikian berarti ada hubungan linier antara menonton iklan di televisi dengan sosial budaya. Kemudian untuk mengetahui tingkat signifikansi kedua variabel, dapat dilihat pada tabel output correlasi :

\begin{tabular}{|c|c|c|c|c|c|}
\hline \multicolumn{6}{|c|}{ Correlations } \\
\hline & & Iklan & Beribadah & $\begin{array}{c}\text { Berkeluarg } \\
\text { a }\end{array}$ & $\begin{array}{c}\text { Bermasyarak } \\
\text { at }\end{array}$ \\
\hline \multirow[t]{3}{*}{ Iklan } & $\begin{array}{l}\text { Pearson } \\
\text { Correlation }\end{array}$ & 1 &, $569^{* *}$ & $463^{* *}$ & $636^{* *}$ \\
\hline & Sig. (2-tailed) & & ,000 & , 000 & ,000 \\
\hline & $\mathrm{N}$ & 399 & 399 & 399 & 399 \\
\hline
\end{tabular}


FITRAH Jurnal Kajian Ilmu-ilmu Keislaman

Vol. 02 No. 2 Desember 2016

\begin{tabular}{llrrrr}
\hline Beribadah & $\begin{array}{l}\text { Pearson } \\
\text { Correlation }\end{array}$ &, $569^{* *}$ & 1 &, $555^{* *}$ &, $535^{* *}$ \\
\cline { 2 - 6 } & Sig. (2-tailed) &, 000 & &, 000 &, 000 \\
\cline { 2 - 6 } & $\mathrm{N}$ & 399 & 399 & 399 & 399 \\
\hline $\begin{array}{l}\text { Berkeluarg } \\
\text { a }\end{array}$ & $\begin{array}{l}\text { Pearson } \\
\text { Correlation }\end{array}$ &, $463^{* *}$ &, $555^{* *}$ & 1 &, $501^{* *}$ \\
\cline { 2 - 6 } & Sig. (2-tailed) &, 000 &, 000 & & 390 \\
\cline { 2 - 6 } & $\mathrm{N}$ & 399 & 399 & 399 & 1 \\
\hline $\begin{array}{l}\text { Bermasyara } \\
\text { kat }\end{array}$ & $\begin{array}{l}\text { Pearson } \\
\text { Correlation }\end{array}$ &, $636^{* *}$ &, $535^{* *}$ &, $501^{* *}$ & 399 \\
\cline { 2 - 6 } & Sig. (2-tailed) &, 000 &, 000 &, 000 & 399 \\
\cline { 2 - 6 } & $\mathrm{N}$ & 399 & 399 & 399 & \\
\hline
\end{tabular}

**. Correlation is significant at the 0.01 level (2-tailed).

Pada angka korelasi Pearson terlihat angka $0,569^{* *} 0,463^{* *}$ dan $636^{*}$ untuk korelasi iklan dengan ibadah sosial, berkeluarga dan bermasyarakat. Masingmasing di belakang angka korelasi terdapat tanda bintang dua $\left({ }^{* *}\right)$. Hal ini menunjukkan bahwa menonton iklan memiliki korelasi yang sangat signifikan dengan ketiga sub variabel sosial budaya masyarakat kota Medan dengan tingkat kepercayaan $99 \%$.

2. Pengujian Hipotesis 2

Hipotesis 2 adalah "Menonton sinetron di televisi berpengaruh terhadap sosial budaya masyarakat muslim kota Medan". Hipotesis ini diuji dengan menggunakan regresi sederhana.

Berdasarkan perhitungan dengan menggunakan alat bantu SPSS, diketahui bahwa $(b)$ tidak sama dengan nol $(b \neq 0)$. Dengan demikian berarti ada hubungan signifikan antara menonton sinetron dengan sosial budaya masyarakat muslim kota Medan. Kemudian untuk mengetahui tingkat signifikansi kedua variabel, dapat dilihat pada tabel output correlation sebagai berikut:

\section{Correlations}

\begin{tabular}{|c|c|c|c|c|c|}
\hline & & $\begin{array}{c}\text { Beribad } \\
\text { ah }\end{array}$ & $\begin{array}{c}\text { Berkeluarg } \\
\text { a } \\
\end{array}$ & $\begin{array}{c}\text { Bermasyarak } \\
\text { at }\end{array}$ & Sinetron \\
\hline \multirow[t]{3}{*}{ Beribadah } & $\begin{array}{l}\text { Pearson } \\
\text { Correlation }\end{array}$ & 1 &, $555^{* *}$ &, $535^{* *}$ & $494^{* *}$ \\
\hline & Sig. (2-tailed) & & ,000 & ,000 & ,000 \\
\hline & $\mathrm{N}$ & 399 & 399 & 399 & 399 \\
\hline \multirow[t]{3}{*}{ Berkeluarga } & Pearson & $555^{* *}$ & 1 &, $501^{* *}$ & $402^{* *}$ \\
\hline & Sig. (2-tailed) & , 000 & & ,000 & ,000 \\
\hline & $\mathrm{N}$ & 399 & 399 & 399 & 399 \\
\hline
\end{tabular}




\begin{tabular}{|ll|r|r|r|r|}
\hline $\begin{array}{l}\text { Bermasyarak } \\
\text { at }\end{array}$ & Pearson &, $535^{* *}$ &, $501^{* *}$ & 1 &, $315^{* *}$ \\
& Correlation & & & \\
& Sig. (2-tailed) &, 000 &, 000 & &, 000 \\
$\mathrm{~N}$ & 399 & 399 & 399 & 399 \\
\hline Sinetron & Pearson &, $494^{* *}$ &, $402^{* *}$ &, $315^{* *}$ & 1 \\
& Correlation & & & & \\
& Sig. (2-tailed) &, 000 &, 000 &, 000 & \\
& $\mathrm{~N}$ & 399 & 399 & 399 & 399 \\
\hline
\end{tabular}

**. Correlation is significant at the 0.01 level (2-tailed).

Pada angka korelasi Pearson terlihat angka $0,555^{* *} 0,535^{* *}$ dan $494^{*}$ untuk korelasi menonton sinetron dengan ibadah sosial, berkeluarga dan bermasyarakat. Masing-masing di belakang angka korelasi terdapat tanda bintang du (**). Hal ini menunjukkan bahwa menonton iklan memiliki korelasi yang sangat signifikan dengan ketiga sub variabel sosial budaya masyarakat kota Medan dengan tingkat kepercayaan 99\%.

3. Pengujian Hipotesis 3

Hipotesis 3 adalah "Menonton iklan, sinetron dan infotainmen di televisi secara bersama-sama berpengaruh terhadap sosial budaya masyarakat muslim kota Medan ." Sosial budaya yang dimaksud mencakup: ibadah sosial, berkeluarga dan bermasyarakat. Hipotesis ini diuji dengan menggunakan regresi berganda.

Untuk menjawab hipotesis di atas dapat dilihat nilai $\mathrm{R}^{2}$ pada tabel model summary sebagai berikut :

Model Summary

\begin{tabular}{|l|r|r|r|r|}
\hline Model & R & R Square & $\begin{array}{c}\text { Adjusted R } \\
\text { Square }\end{array}$ & $\begin{array}{c}\text { Std. Error of } \\
\text { the Estimate }\end{array}$ \\
\hline 1 &, $638^{\mathrm{a}}$ &, 407 &, 404 & 4,43466 \\
\hline
\end{tabular}

a. Predictors: (Constant), Iklan, Sinetron

Pada tabel Model Summary diperoleh $\mathrm{R}^{2}=0,407$. Artinya menonton iklan dan sinetron secara bersama-sama dapat menerangkan variabilitas sebesar 40,7\% dari variabilitas ibadah sosial masyarakat muslim kota Medan. Sedangkan sisanya diterangkan oleh variabel lain (dimana $\mathrm{R}^{2}$ merupakan koefisien determinasi).

\begin{tabular}{|l|r|r|r|r|}
\hline Model & $\mathrm{R}$ & R Square & $\begin{array}{c}\text { Adjusted R } \\
\text { Square }\end{array}$ & $\begin{array}{c}\text { Std. Error of } \\
\text { the Estimate }\end{array}$ \\
\hline 1 &, $519^{\mathrm{a}}$ &, 270 &, 266 & 2,44136 \\
\hline
\end{tabular}

a. Predictors: (Constant), Iklan, Sinetron 
Pada tabel Model Summary diperoleh $\mathrm{R}^{2}=0,270$. Artinya menonton iklan dan sinetron secara bersama-sama dapat menerangkan variabilitas sebesar $27,0 \%$ dari variabilitas berkeluarga masyarakat muslim kota Medan. Sedangkan sisanya diterangkan oleh variabel lain (dimana $\mathrm{R}^{2}$ merupakan koefisien determinasi).

\begin{tabular}{|l|r|r|r|r|}
\hline Model Summary \\
\hline 1 & R & R Square & $\begin{array}{c}\text { Adjusted R } \\
\text { Square }\end{array}$ & $\begin{array}{r}\text { Std. Error of } \\
\text { the Estimate }\end{array}$ \\
\hline
\end{tabular}

a. Predictors: (Constant), Iklan, Sinetron

Pada tabel Model Summary diperoleh $\mathrm{R}^{2}=0,409$. Artinya menonton iklan dan sinetron secara bersama-sama dapat menerangkan variabilitas sebesar 40,9\% dari variabilitas bermasyarakat masyarakat muslim kota Medan. Sedangkan sisanya diterangkan oleh variabel lain (dimana $\mathrm{R}^{2}$ merupakan koefisien determinasi).

\section{PENUTUP}

Dari paparan penelitian di atas, dapat disimpulkan sebagai berikut :

1. Menonton iklan di televisi memberikan efek yang positif dengan tingkat sangat signifikan terhadap sosial budaya masyarakat kota Medan

2. Menonton sinetron di televisi memberikan efek yang positif dengan tingkat sangat signifikan terhadap sosial budaya masyarakat kota Medan.

3. Menonton iklan dan sinetron secara bersama-sama memberikan efek terhadap sosial budaya masyarakat kota Medan yang mencakup ibadah sosial, berkeluarga dan bermasyarakat dengan masing-masing variabilitas $0,407,0,270$ dan 0,409 . 


\section{DAFTAR PUSTAKA}

Arikunto, Suharsimi, Prosedur Penelitian Suatu Pendekatan Praktek (Jakarta: Rineka Cipta, 1983).

Badjuri, Adi. Jurnalistik Televisi (Jogjakarta: Graha Ilmu, 2010).

BPS Kota Medan tahun 2011

Bungin, M.Burhan, Sosiologi Komunikasi : Teori, Paradigma dan Diskursus Teknologi Komunikasi di Masyarakat (Jakarta : Kencana, 2006).

Kholil ,Syukur, Metodologi Penelitian Komunikasi (Bandung: Citapustaka Media, 2006).

Kriyantono, Rakhmat, Teknik Praktis Riset Komunikasi, (Jakarta: Kencana Prenada Media, 2006).

Kuswandi, Wawan, Komunikasi Massa Sebuah Analisis Media Televisi (Jakarta : Rineka Cipta, 1996).

Mulyana, Dedi, Ilmu Komunikasi Suatu Pengantar. Bandung: Remaja Rosdakarya, 2007.h

Nashrillah, Pola Menonton Siaran Agama di Televisi dan Pengaruhnya Terhadap Pengamalan Agama Ibu-Ibu Pengajian Aisyiah Kecamatan Medan Timur-Tesis, (Medan: PPs IAIN-SU,2007).

Rakhmat, Jalaluddin, Psikologi Komunikasi (Bandung: Rosda Karya, 2002).

Rakhmat, Jalaluddin. Islam Aktual (Bandung: Mizan, 1995).

Samover, Larry A, Richard E. Poter dan Lisa A. Stefany. Communication Between Cultures. Edisi-3 Belmint, CAWadsworth, 1998.

Soekanto, Soerjono, Sosiologi Suatu Pengantar. Jakarta: Raja Grapindo Persada, 1995.

Syaifullah, Ujang, Kapita Selekta Komunikasi, Bandung: Simbiosa Rekatama Media, 2007.

Wahid Sulaiman, Jalan Pintas Menguasai SPSS (Yogyakarta: Andi, 2002). 
FITRAH Jurnal Kajian Ilmu-ilmu Keislaman

Vol. 02 No. 2 Desember 2016

Walisyah T, Hubungan Iklan Makanan Ringan Di Televisi Dan Status Sosial Ekonomi Dengan Sikap Konsumtif Anak-Anak Sekolah Dasar Negeri Di Kecamatan Tanjung Morawa (Medan: PPs IAIN-SU).

Wawan Kuswandi, Komunikasi Massa Sebuah Analisis Media Televisi, (Jakarta: Rineka Cipta,1996)

Zuckerman, et al., “Television Viewing, Children's Reading and Related Classroom Behavior". Journal of Communication 30 (1), 1980, 